\title{
Unpacking the Engineering Process
}

\section{Resourcing Trade Books and Biographies}

\author{
JULIE JACKSON, MICHELLE FORSYTHE, DANIELLE MEDEIROS, JOSEPH PARTHEMORE, AND ALEXIS RIX
}

$\mathrm{I}$ nterest in engineering education is growing, and libraries are often the hub of science, technology, engineering, and mathematics (STEM) learning activities in schools and communities. To enhance patrons' experiences, many libraries have incorporated making, maker, and tinkering spaces that support STEM learning and engineering thinking. Making, maker, and tinkering spaces generally include opportunities for patrons to have hands-on experiences with a variety of materials, technology resources, and design challenges that encourage thinking like an engineer. This type of thinking is "goal-oriented thinking that addresses problems and decisions within given constraints by drawing on available resources, both material resources and human capital." ${ }^{1}$ Thinking like an engineer, making, and tinkering are all part of engineering design-based learning.

The focus on engineering design-based learning began with the release of the Next Generation Science Standards (NGSS) in 2013, when the NGSS introduced "engineering design as an essential element of science education."2 In the ensuing years, there has been an explosion of efforts by educators to include engineering design in educational experiences and an increase in the popularity of STEM education. ${ }^{3}$ The Framework for K-12 Science Education defines engineering as "any engagement in a systematic practice of design to achieve solutions to particular human problems," ${ }^{4}$ and it notes that engineers use the engineering design process (EDP) and their problem-solving skills to improve the human condition. The framework cautions that "engineering is not just applied science ... and engineering design has a different purpose and product than scientific inquiry." "Engineers constantly discover how to improve lives by creating bold new solutions that connect science to life in unexpected ways," ${ }^{6}$ and scientists study the natural world seeking evidence-based explanations.
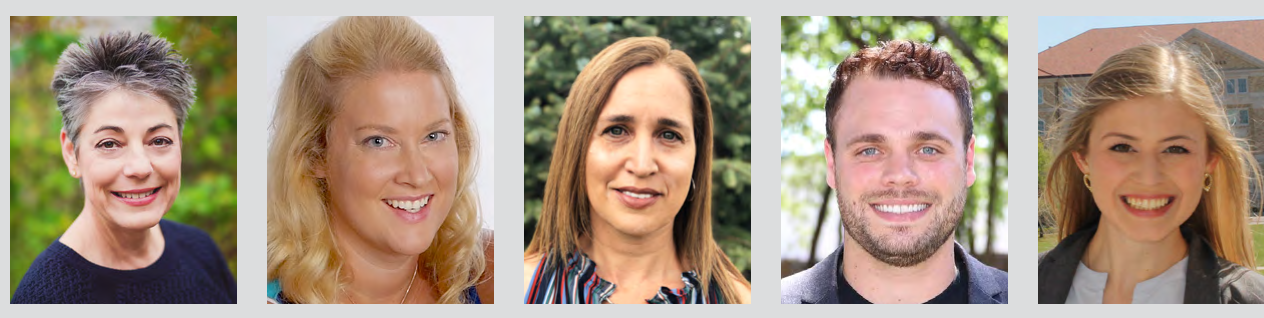

Julie Jackson is an associate professor of science education at Texas State University in San Marcos, TX. Michelle Forsythe is an assistant professor of STEM education at Texas State University in San Marcos, TX. Danielle S. L. Medeiros is a graduate student at Texas State University in San Marcos, TX. Joseph Parthemore is a 5th grade math and science teacher at Cannon Elementary School in Grapevine, TX. His exemplary teaching provides 21st Century learning experiences that are preparing students for the STEM future. Alexis Rix orchestrates literacy and civics instruction alongside science, technology, engineering, and math experiences as a teacher at Cannon Elementary School in Grapevine, TX. 
The engineering community is working to ensure that STEM education and informal STEM experiences accurately portray the impact of engineering on our daily lives, the nature of what engineers do, and the role engineers play in the creation or improvement of technologies. They emphasize that engineering and engineers can make a difference in the world through the spirit of innovation and bold new solutions. To help the public and students better understand engineering through this lens, the engineering community proposes that "stories that dramatize the rich legacy of engineering achievements" be used to help "bring the experience of engineering to life."7

To build student understanding of the nature of what engineers do and how engineers apply the EDP to systematically and efficiently solve problems, we use biographies and trade books to study the accomplishments of engineers and inventors. First, students or library patrons read a biography about an engineer or an inventor, or they may read a trade book that contains an obvious problem and a thoughtful solution. Then they analyze aspects of the text such as text features or plot elements to pinpoint problem-solving as it aligns with the EDP. Students formalize their understanding of the EDP when they create a presentation, a project, or an artifact that includes a summary of the problem that the engineer, inventor, or main character faced and how they used each step of the EDP to solve the problem. Hill-Cunningham, Mott, and Hunt propose that the use of children's literature provides a "real life" application for the EDP. ${ }^{8}$

Using books to support instruction is a time-honored tradition. A well-chosen book can generate interest in a topic, present a problem, challenge misconceptions, and explain content. Although choosing appropriate biographies and trade books that support the EDP can be a challenge, the National Science Teachers Association (NSTA) reviews hundreds of books yearly and publishes their recommendations as the Best STEM Books K-12 list, which can be found at www. nsta.org/publications/stembooks/. In addition, the NSTA journal Science and Children includes a Teaching Through Trade Books column that recommends two STEM books per issue.

The Engineering is Elementary (EiE) program from the Museum of Science in Boston includes web-based content area support materials that highlight children's literature connections for the engineering topics included in their curriculum. ${ }^{9}$ These reliable resources are a great place to find trade books that support engineering design and engineering thinking. ${ }^{10}$

The EDP is an iterative series of steps that guide engineers as they seek solutions to problems. There are several accepted versions of the EDP, and all of them include a continuous cycle "that enables engineers to continually enhance and improve their design [prototypes] through repeated testing, analysis, and redesign." 11 The redesign phase is important. This is where engineers and inventors make improvements to their

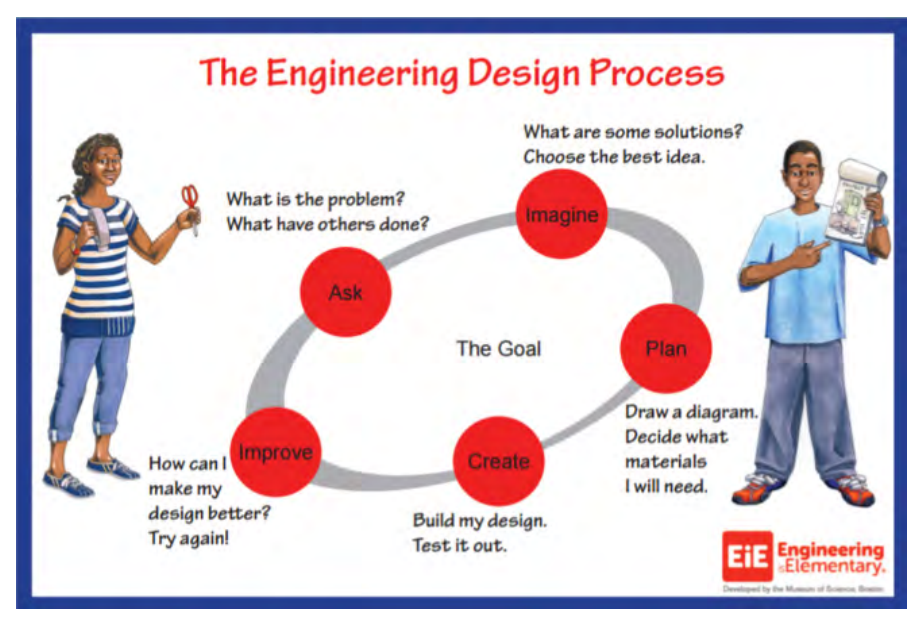

Figure 1. Engineering is Elementary Engineering Design Process.

prototype based on what they learn when a prototype fails or performs in unexpected ways.

The Museum of Science, Boston, EiE program incorporates an easy to understand model of the EDP (see figure 1). The EiE EDP model includes a goal and five steps: Ask, Imagine, Plan, Create \& Test, and Improve. ${ }^{12}$ This is the model we use with our students. Because the EDP is a cycle, it may be entered at any point. Sometimes failure of a prototype leads inventors or engineers to ask questions and brainstorm possible redesigns. Other times the goal is to improve an existing technology to enhance function or expand application.

By using well-chosen trade books and biographies, students can discover or reverse-engineer the EDP past inventors have used. We use picture-book biographies and trade books with lower elementary students and chapter book biographies with upper elementary students. Biographies of engineers and inventors are good vehicles to illustrate the EDP because they "provide a linear, chronological sequence of events with a framework that assists readers in developing their understanding about the person-of-study and that individual's achievements." ${ }^{13}$

Librarians can direct classroom teachers seeking STEM or engineering support to use picture-book biographies, chapter book biographies, and trade books to illustrate how engineers and inventors apply the EDP to address problems and develop workable solutions or improve technology. Table 1 includes examples of picture-book biographies that contain clear examples of the EDP. Manfish: A Story of Jacques Cousteau by Jennifer Berne and Éric Puybaret introduces Jacques Cousteau and explains how his love for underwater adventure began. It describes several of the tools he invented or improved in order to study and photograph marine environments. Whoosh! Lonnie Johnson's Super-Soaking Stream of Inventions by Chris Barton and Don Tate includes a humorous retelling of a failed design test that underpinned Lonnie Johnson's Super Soaker water gun invention. Balloons over Broadway: The True Story of the Puppeteer of Macy's Parade by Melissa Sweet reveals that many years ago, Macy's annual 


\begin{tabular}{|c|c|c|c|c|c|}
\hline & Ask & Imagine & Plan & Create \& Test & Improve \\
\hline $\begin{array}{l}\text { Manfish: A Story of } \\
\text { Jacques Cousteau }\end{array}$ & $\begin{array}{l}\text { Jacques Cousteau was } \\
\text { fascinated by movies, } \\
\text { and he wondered how } \\
\text { cameras worked. }\end{array}$ & $\begin{array}{l}\text { He saved his allowance } \\
\text { so he could buy a } \\
\text { camera. He dreamed } \\
\text { of making movies. }\end{array}$ & $\begin{array}{l}\text { He bought a camera } \\
\text { and took it apart and } \\
\text { then reassembled it. } \\
\text { He planned to use the } \\
\text { camera to make lots of } \\
\text { movies. }\end{array}$ & $\begin{array}{l}\text { He made home movies } \\
\text { of his family. Then he } \\
\text { joined the French Navy } \\
\text { and he filmed what he } \\
\text { saw when he traveled. }\end{array}$ & $\begin{array}{l}\text { Jacques created a } \\
\text { waterproof case for his } \\
\text { camera so he could } \\
\text { make movies about } \\
\text { what he saw when he } \\
\text { swam underwater. }\end{array}$ \\
\hline $\begin{array}{l}\text { Whoosh! Lonnie } \\
\text { Johnson's Super- } \\
\text { Soaking Stream of } \\
\text { Inventions }\end{array}$ & $\begin{array}{l}\text { Lonnie wondered if } \\
\text { refrigerators could use } \\
\text { water and air pressure } \\
\text { to keep food cool. }\end{array}$ & $\begin{array}{l}\text { He attached a pump } \\
\text { and water hose to a } \\
\text { water faucet. When } \\
\text { he turned it on, water } \\
\text { blasted out of the } \\
\text { nozzle. He thought, } \\
\text { "This would make this a } \\
\text { great water gun." }\end{array}$ & $\begin{array}{l}\text { He gathered materials } \\
\text { that he could use to } \\
\text { build a safe, child- } \\
\text { friendly water gun. }\end{array}$ & $\begin{array}{l}\text { He built a prototype } \\
\text { water gun and tested } \\
\text { it out at a picnic. It } \\
\text { worked! }\end{array}$ & $\begin{array}{l}\text { He improved the } \\
\text { prototype. He worked } \\
\text { hard to find a toy } \\
\text { company that would } \\
\text { manufacture it. The } \\
\text { Super Soaker is one of } \\
\text { the most popular toys } \\
\text { sold today. }\end{array}$ \\
\hline
\end{tabular}

Table 2. Chapter book biography EDP examples

\begin{tabular}{|c|c|c|c|c|c|}
\hline & Ask & Imagine & Plan & Create \& Test & Improve \\
\hline $\begin{array}{l}\text { Frozen in Time: } \\
\text { Clarence Birdseye's } \\
\text { Outrageous Idea } \\
\text { about Frozen Food }\end{array}$ & $\begin{array}{l}\text { Clarence Birdseye } \\
\text { wondered how he } \\
\text { could preserve food so } \\
\text { his family could have } \\
\text { good-tasting food } \\
\text { during the winter. }\end{array}$ & $\begin{array}{l}\text { Mr. Birdseye noticed } \\
\text { that freshly-caught } \\
\text { fish froze immediately } \\
\text { when exposed to the } \\
\text { freezing air in Canada. } \\
\text { He decided to create } \\
\text { a machine that could } \\
\text { freeze food as quickly } \\
\text { as possible. }\end{array}$ & $\begin{array}{l}\text { Using available } \\
\text { information and } \\
\text { results from his own } \\
\text { investigations, he } \\
\text { patented an indirect, } \\
\text { quick freezing and } \\
\text { product packaging } \\
\text { processes that could } \\
\text { freeze food fast at very } \\
\text { low temperatures. }\end{array}$ & $\begin{array}{l}\text { He built a multiplate } \\
\text { freezing machine that } \\
\text { eliminated air in the } \\
\text { packaging process. } \\
\text { He used an ammonia- } \\
\text { based refrigerant. } \\
\text { Consumers were slow } \\
\text { to trust frozen food. }\end{array}$ & $\begin{array}{l}\text { He switched to a } \\
\text { metal belt system } \\
\text { and began using a } \\
\text { calcium chloride spray } \\
\text { to cool the belts. He } \\
\text { also started dipping } \\
\text { vegetables in boiling } \\
\text { water before freezing } \\
\text { to improve the color. }\end{array}$ \\
\hline $\begin{array}{l}\text { Who Were the Wright } \\
\text { Brothers? }\end{array}$ & $\begin{array}{l}\text { The Wright brothers } \\
\text { asked themselves, } \\
\text { "How can we build } \\
\text { a successful flying } \\
\text { machine?" }\end{array}$ & $\begin{array}{l}\text { The brothers read } \\
\text { about ballooning, } \\
\text { gliding, and existing } \\
\text { flying machines. They } \\
\text { wrote to people all } \\
\text { over the world who } \\
\text { shared their dream of } \\
\text { flying. }\end{array}$ & $\begin{array}{l}\text { They learned from their } \\
\text { previous attempts. They } \\
\text { also watched birds fly } \\
\text { and noticed how birds } \\
\text { twisted the tips of their } \\
\text { wings for balance. }\end{array}$ & $\begin{array}{l}\text { They built a large } \\
\text { biplane kite. They built } \\
\text { over } 1000 \text { gliders. In } \\
\text { 1903, they built their } \\
\text { first flying machine that } \\
\text { could carry a person; it } \\
\text { broke on the first try. }\end{array}$ & $\begin{array}{l}\text { On December 17, } \\
\text { 1903, their power- } \\
\text { driven, heavier-than-air } \\
\text { machine took flight. } \\
\text { They had built the } \\
\text { first successful flying } \\
\text { machine. }\end{array}$ \\
\hline
\end{tabular}

parade included live lions and bears that roared and scared small children. The parade committee decided to replace the live animals with something that would not terrify children, and after several tests and redesigns, the famous Macy's parade balloon puppets were created.

Table 2 includes examples of chapter book biographies that showcase how the EDP is woven into descriptions of engineers' or inventors' achievements. The book Frozen in Time: Clarence Birdseye's Outrageous Idea about Frozen Food by Mark Kurlansky describes Birdseye's efforts to find a way to freeze food quickly so it could be stored and then eaten outof-season. Who Were the Wright Brothers? by James Buckley Jr. outlines how Orville and Wilbur Wright successfully leveraged what they knew about bicycles and how birds flew to design and test the first successful flying machine.

Table 3 highlights how the EDP is present in trade books that include a problem or task, a review of a plan of action, the creation and testing of a prototype, and a reasonable, workable solution. Rosie Revere, Engineer by Andrea Beaty introduces Rosie and her efforts to create a flying "gizmo" for her aunt. Ada's Violin: The Story of the Recycled Orchestra of Paraguay by
Susan Hood recounts the true story of a father's efforts to use recycled material found in a landfill to create musical instruments for a youth orchestra. The Most Magnificent Thing by Ashley Spires delightfully illustrates the frustration and angst that can occur during the create, test, and redesign phases of the EDP.

Once students and librarians are familiar with the stages of the EDP, librarians can reinforce engineering thinking during a read-aloud by placing blank EDP templates in their making and tinkering spaces. During a read-aloud, librarians can request that students track and report the distinct stages of the EDP that occur during the story. Students can create response sticks labeled with each EDP stage (see figure 2).

Then, during the read-aloud, students raise the corresponding response stick whenever they notice a particular EDP stage in action (see figure 3 ).

If students are not familiar with the EDP or if they require scaffolding, librarians can place a Google EDP and biography HyperDoc on the library webpage. Google HyperDocs are tools or lessons created to frame students' use of technology 

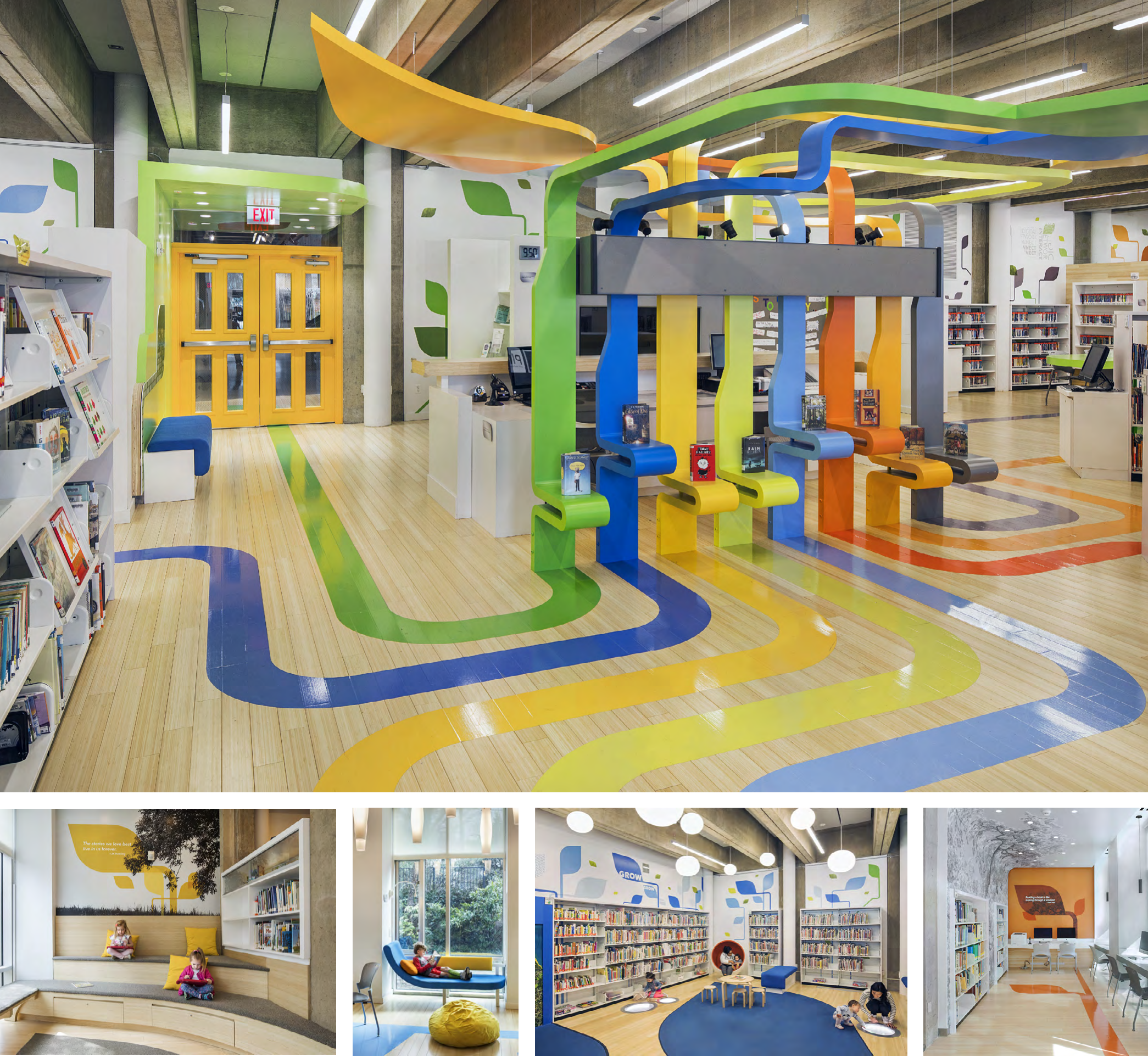

THE JACKIE AND HAROLD SPIELMAN CHILDREN'S LIBRARY at Port Washington Public Library, NY

Winner of:

- The Long Island AIA Archi Award, Best Non-Residential Interior

- The Benjamin Moore \& Company Color Award

- 2018 A|N Best of Design Awards Honorable Mention, Interior Institutional Category

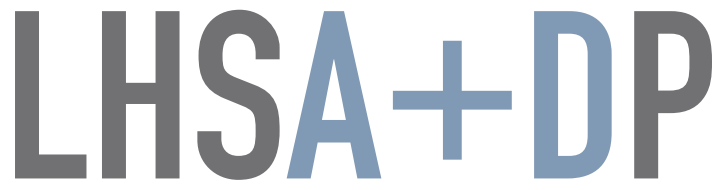

Lee H. Skolnick Architecture + Design Partnership Tel: 212-989-2624 skolnick.com 


\begin{tabular}{|c|c|c|c|c|c|}
\hline & Ask & Imagine & Plan & Create \& Test & Improve \\
\hline Rosie Revere, Engineer & $\begin{array}{l}\text { Rosie wondered if she } \\
\text { could build a gizmo to } \\
\text { help her aunt achieve } \\
\text { her dream of flying. }\end{array}$ & $\begin{array}{l}\text { Rosie stayed awake all } \\
\text { night trying to imagine } \\
\text { how she could create } \\
\text { a flying gizmo for her } \\
\text { aunt. }\end{array}$ & $\begin{array}{l}\text { She thought about } \\
\text { everything she had } \\
\text { ever invented, and she } \\
\text { had a plan by morning. }\end{array}$ & $\begin{array}{l}\text { Rosie created and } \\
\text { tested a cheese- } \\
\text { copter. It flew a few } \\
\text { minutes then crashed. }\end{array}$ & $\begin{array}{l}\text { Rosie and her aunt } \\
\text { made design changes } \\
\text { to improve the cheese- } \\
\text { copter. }\end{array}$ \\
\hline $\begin{array}{l}\text { Ada's Violin: The } \\
\text { Story of the Recycled } \\
\text { Orchestra of Paraguay }\end{array}$ & $\begin{array}{l}\text { Ada needed her own } \\
\text { violin so she could } \\
\text { practice at home. Her } \\
\text { father wondered how } \\
\text { he could make a violin. }\end{array}$ & $\begin{array}{l}\text { He remembered } \\
\text { learning about a band } \\
\text { that made their own } \\
\text { instruments. }\end{array}$ & $\begin{array}{l}\text { He asked a carpenter } \\
\text { to help him make } \\
\text { musical instruments out } \\
\text { of trash. They searched } \\
\text { the local landfill to find } \\
\text { objects they could } \\
\text { use to make musical } \\
\text { instruments. }\end{array}$ & $\begin{array}{l}\text { They experimented } \\
\text { with different items they } \\
\text { found in the landfill, } \\
\text { looking for material and } \\
\text { objects that they could } \\
\text { use to make musical } \\
\text { instruments. }\end{array}$ & $\begin{array}{l}\text { They transformed } \\
\text { oil drums into cellos, } \\
\text { water pipes into flutes, } \\
\text { packing crates into } \\
\text { guitars, and an old } \\
\text { paint can, baking tray, } \\
\text { fork, and pieces of } \\
\text { wood into a violin. }\end{array}$ \\
\hline
\end{tabular}

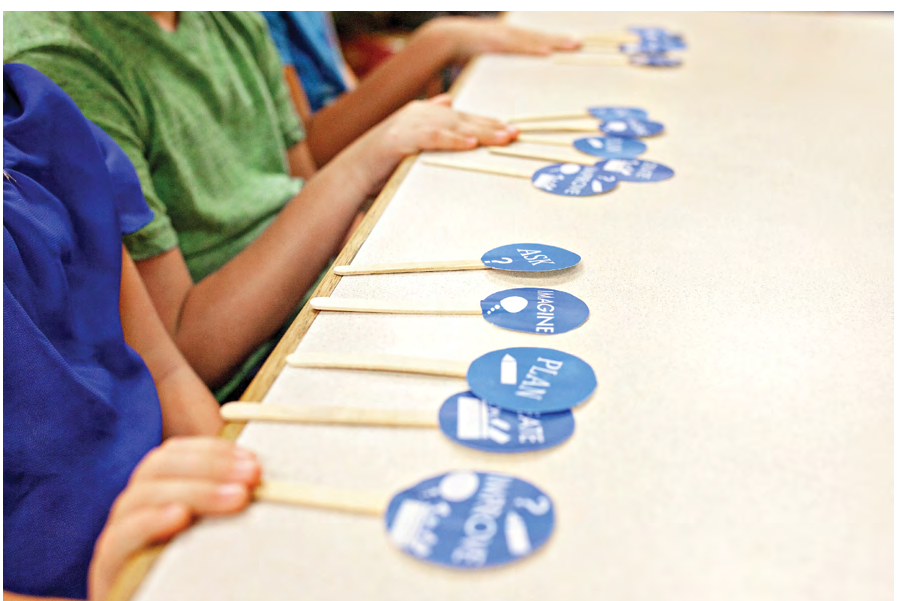

Figure 2. Students creating response sticks to identify the EDP stages

to connect and collaborate with other students, construct knowledge, and think critically.

HyperDocs often include scaffolding hyperlinks that direct students to easy-to-use websites and web tools that provide support and helpful explanations. The EDP framing the biography HyperDoc included here was modified by an elementary STEM academy. The revised EDP includes imagine, plan, design, improve, and communicate steps and each step is hyperlinked to the Design Squad Nation website. ${ }^{14}$ The Design Squad website contains links to easy-to-understand written descriptions and video examples of each step of the EDP. The HyperDoc also includes space for students to identify how the person-of-study or main character of a trade book used the EDP to solve a problem and create a workable solution to make life better for people. The interactive engineers/inventor biography Google HyperDoc is available at https://goo.gl/EYuZvp.

Using information included in the biography chapter book The Inventions of Alexander Graham Bell: The Telephone by Holly Cefrey, a pair of fifth grade students reverse engineered Bell's EDP and entered their ideas in the biography HyperDoc.

The students noted that Alexander Graham Bell identified a problem-slow communication methods that relied on ships

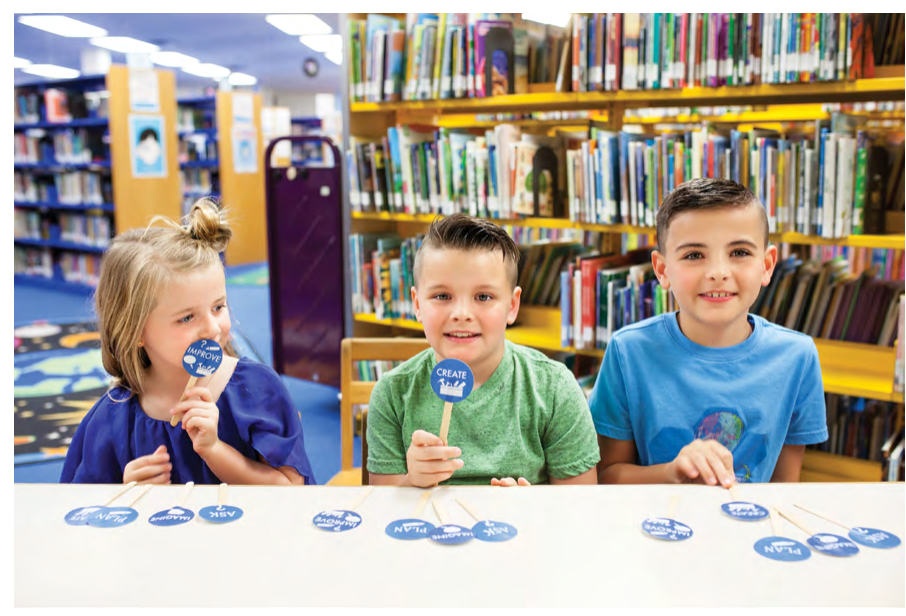

Figure 3. Students using response sticks to identify the EDP stages

or horse carriages. He imagined a faster way to communicate using existing material. He built prototypes and tested and improved them until he had a working telephone. Then he communicated his findings to the world. Completed EDP projects may be displayed in the library maker space, posted on the library webpage, or in another appropriate location.

As an extension, students could engineer an improvement of the innovation studied in order to create their own prototype. Then students would become not only STEM analyzers but engineers themselves.

Libraries regularly provide patrons with making and tinkering spaces that support STEM education. We believe that libraries can also support engineering design-based learning and engineering thinking by harnessing the power of biographies and trade books that accurately portray the impact of engineering on our daily lives, the nature of what engineers do, and the role engineers play in the creation and improvement of technologies. Biographies about engineers and inventors, as well as trade books with identifiable problems that create and test prototypes and portray workable solutions, 
KA: I'm an animal lover; I've always been an animal lover; I was a crazy horse girl. I have five cats-they showed up on our door. I'm right on the verge of being a crazy cat woman.

Some readers/adults expressed initial concern about the animal abuse depicted in The Underneath.

KA: When the book first came out, I had some hate mail...feelings were very strong. But animal abuse is very real. Kids need to know that-those emotional rehearsals where they can experience sadness and grief. A book is a safe place to have those experiences.

The Underneath takes place in a very distinct setting; how did you come to set it in a bayou near the Louisiana/Texas border?

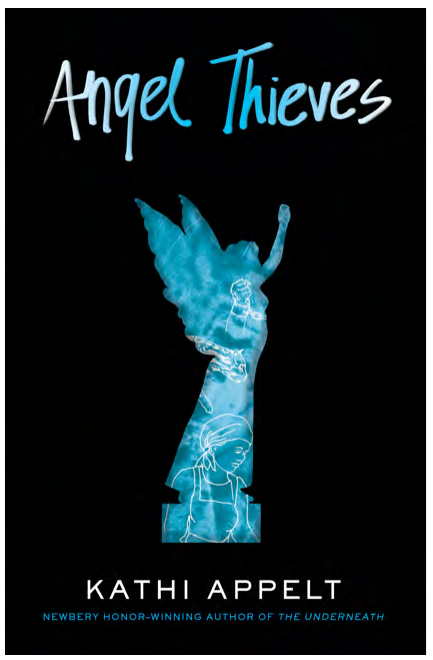

back there, and probably does. It's so mysterious at the same time. When I was writing The Underneath, I recalled those feelings. Who's to say there aren't ancient alligators in the swamps of East Texas?

What did winning a Newbery Honor mean to you?

KA: That was life changing; it was amazing. I worked hard to put my heart in that book. It had so much of me in it. Things from my past were in it; it meant a lot to me.

\section{What's next for you?}

KA: Max Attacks is a picturebook in the pipeline with Simon \& Schuster, as well as a young adult novel in spring 2019 with a magical realism bent, Angel Thieves. It has contemporary and historical storylines about a man and his

KA: The natural world intrigues me. In college, I moved to East Texas with my sister; we lived in this tiny cabin. It was really back in the woods. Once you lived there . . . it has this sense of being old and remote and it feels like anything can happen son who live in an antiques store and they steal cemetery angels. The back story is based on a true story about a slave who lived in pre-Civil War Houston. ¿

"Unpacking the Engineering Process" continued from page 8

are resources that can be easily leveraged to support STEM initiatives. $\&$

\section{References}

1. Christine Lippard, Monica Lamm, and Katie Riley, "Engineering Thinking in Prekindergarten Children: A Systematic Literature Review," Journal of Engineering Education 106, no. 3 (2017): 455.

2. NGSS Lead States, Next Generation Science Standards: For States, by States, (Washington, DC: National Academies Press, 2013), 437.

3. Norman Fortenberry, "What is Engineering's Plan in STEM Certification? ASEE Responds," National Science Teachers Association Blog, January 25, 2018, http://nsta communities.org/blog/2018/01/25/what-is-engineer ings-place-in-stem-certification-asee-responds/.

4. NGSS Lead States, Next Generation Science Standards: For States, by States, 437.

5. Ibid.

6. National Academy of Engineering, Changing the Conversation: Messages for Improving Public Understanding of Engineering (Washington, DC: National Academies Press, 2008), 100.

7. Ibid 44 .
8. P. Renee Hill-Cunningham, Michael Mott, and AnnaBlair Hunt, "Facilitating an Elementary Engineering Design Process Module," School Science and Mathematics 118, no. 1-2 (2018): 55.

9. "EiE Content Area Connections," Engineering is Elementary, www.eie.org/eie-curriculum/eie-content -area-connections\#alarms.

10. Michelle Forsythe, Julie Jackson, and Leo Contreras, "Hiding in Plain Sight: How to Identify and Use Trade Books to Support the 5E Instructional Model," Science and Children 56, no. 2 (In Press).

11. Carolyn Parker, Erica Smith, David McKinney, and Amanda Laurier, "The Application of the Engineering Design Proves to Curriculum Revision: A Collaborative Approach to STEM Curriculum Refinement in an Urban District," School Science and Mathematics 116, no. 7 (2016): 400.

12. "The Engineering Design Process," Engineering is Elementary, www.eie.org/engineering-adventures /engineering-design-process.

13. Donna Werderich, Pamela Farris, and Alice McGinty, "Methods and Strategies: Biography as Mentor," Science and Children 52, no. 2 (2014): 66.

14. “The Design Process,” Design Squad Nation, http://pbs .panda-prod.cdn.s3.amazonaws.com/media/assets /wgbh/adptech12/adptech12_int_idsprocess/index.html. 